\title{
A FESTA POPULAR NA REPÚBLICA SOB A PERSPECTIVA DE JEAN-JACQUES ROUSSEAU
}

\author{
THE POPULAR FESTIVITY IN THE REPUBLIC IN THE \\ PERSPECTIVE OF JEAN-JACQUES ROUSSEAU
}

\author{
Vital Francisco Celestino Alves ${ }^{1}$ \\ Recebido em:05/2018 \\ Aprovado em: 11/2018
}

\begin{abstract}
Resumo: Ao apresentar em sua Carta a D'Alembert a discordância à proposta da criação de um Teatro de Comédia em Genebra, Rousseau paralelamente expõe uma exaltação à festa popular. Buscando examinar a concepção de "festa popular" no pensamento rousseauniano, e defendendo a hipótese de que é possível compreender de que maneira a festa popular pode contribuir para a longevidade da república a partir da análise de alguns aspectos da Carta a D'Alembert e das Considerações sobre o governo da Polônia, o presente artigo se concentrará em quatro pontos: o primeiro, em um exame da proposta de um Teatro de Comédia para Genebra apresentada por D'Alembert; o segundo, na perscrutação da objeção de Rousseau à proposta d'alembertiana; o terceiro, em uma avaliação das razões pelas quais o autor genebrino preconiza que a festa popular é o espetáculo mais apropriado para a República de Genebra; o quarto (tendo como referência o texto sobre a Polônia) consistirá no enfrentamento da seguinte questão: de que maneira a festa popular pode contribuir para a durabilidade da república?
\end{abstract}

Palavras-chave: Teatro de comédia; Festa popular; República; Rousseau.

Abstract: In presenting, in his Letter to D'Alembert, his disagreement with the proposal for the creation of a Comedy Theater in Geneva, Rousseau, concurrently, presents an exaltation of the popular festival. To consider the conception of "popular festival", in Rousseauian thought, and defending the hypothesis that it is possible to understand how the popular festival can contribute towards the longevity of the republic, based on an analysis of certain aspects of the Letter to D'Alembert and the Considerations on the Government of Poland, this article will concentrate on four points: the first, an examination of the proposal, presented by D'Alembert, of a Comedy Theatre for Geneva, second, a careful consideration of Rousseau's objection to D'Alembert's proposal; third, an analysis of the reasons why the Genovese author advocates that the popular festival is the most appropriate spectacle for the republic of Geneva; and fourth, (referring to the text on Poland) facing the following question: how can the popular festival contribute to the preservation of the Republic?

Keywords: Comedy Theater; Popular Festival; Republic; Rousseau.

\section{Um Teatro de Comédia para Genebra}

A festa, identificada como celebração coletiva, foi objeto de uma oportuna reflexão

\footnotetext{
${ }^{1}$ Doutor em filosofia (UFG). Atualmente professor da Unb. E-mail: vitalalves1@gmail.com
} 
suscitada por Rousseau. Ela obtém significativa visibilidade em diversos de seus escritos ${ }^{2}$, e, acima de tudo, faz-se notar na célebre Carta a D'Alembert ${ }^{3}$, reaparece com vivacidade nas Considerações sobre o governo da Polônia e de maneira distinta ressoa no romance epistolar A nova Heloísa e nos Devaneios do caminhante solitário. A festa se torna escopo das análises de Rousseau a partir da polêmica aguçada por D'Alembert ao sugerir a criação de um teatro de comédia em Genebra ${ }^{4}$. Na Carta que Jean-Jacques endereça ao pensador francês, lê-se a resposta contundente do autor da missiva e sua concepção sobre as festividades populares. Compreender a resposta tecida pelo filósofo genebrino implica preliminarmente darmos conta do enfoque d'alembertiano versado na primeira missiva, a qual deflagrou a carta réplica rousseauísta. $\mathrm{Na}$ epístola concebida por D’Alembert, na qual se verifica a sua proposta e justificativa para a fabricação de um teatro de comédia na cidade de Genebra, algumas opiniões se destacam.

Almejando entender o ponto de vista d'alembertiano, seguiremos o compêndio exposto por Rousseau na carta que ele direciona ao escritor francês para, na sequência, examinarmos a perspectiva do genebrino e como o tema da festa popular se inscreve nesse contexto. De maneira condensada, a epístola d'alembertiana alega que a inadmissão da comédia em Genebra advém de uma suposta temeridade de que esse gênero teatral poderia causar ao povo genebrino, uma vez que as companhias de comediantes costumam disseminar entre a juventude um singular gosto por adereços, orgias e licenciosidade. Tal temeridade imputada ao estilo artístico em questão poderia ser prevenida por meio de leis rigorosas e aplicadas acertadamente. Orientandose por essa diligência, haveria em Genebra espetáculos correspondentes ao que se espera deles e simultaneamente a promoção de bons costumes, fazendo com que a cidade desfrutasse dos benefícios de um e outro. Assim, D’Alembert declara que as performances teatrais seriam eficazes na formação do gosto dos cidadãos, conferindo-lhes um refinamento da sensibilidade

\footnotetext{
${ }^{2}$ Bronislaw Baczko (1978) destaca que as referências ao tema da festa são bastante notáveis na obra rousseauniana visto que se constata a imagem da festa "primitiva" no Segundo Discurso e no Ensaio sobre as origens das línguas; na Nova Heloísa, nos deparamos com a renomada festa das Vindimas "espelho mágico" da sociedade de Clarens; na Carta a D'Alembert, testemunhamos o quadro idealizado da festa popular na praça Saint-Gervais em Genebra, e, finalmente, as referências são resgatadas e aprofundadas nas Considerações sobre o governo da Polônia.

${ }^{3} \mathrm{Na}$ maior parte da análise que será realizada buscaremos nos deter principalmente na concepção de "festa popular" que vemos na Carta a D'Alembert, já no último tópico teremos como suporte as Considerações sobre o governo da Polônia.

${ }^{4}$ No livro décimo de suas Confissões, Rousseau declara que foi por meio de uma visita recebida de Diderot, quando residia em Ermitage, que tomou conhecimento acerca do artigo "Genebra" que D'Alembert iria publicar na Enciclopédia e que supostamente havia sido acordado com os genebrinos do alto escalão social. Mediante tal acordo, fixaram-se algumas providências que rapidamente viabilizariam a construção do teatro. Irritado com o fato, o pensador genebrino relata que aguardou ansiosamente pelo volume da Enciclopédia no qual constara o artigo d'alembertiano para averiguar se haveria a possibilidade de postular uma resposta capaz de reverter o que ele denominou de um "duro golpe".
} 
proporcionada pela comédia, em sua plena capacidade disso proporcionar. Logo, seria de considerável vantagem para a literatura, uma vez que a licenciosidade se manteria afastada da cidade, e como resultado, Genebra convergiria a sapiência espartana e a polidez ateniense.

Ao conceder espaço aos espetáculos de comédia, a República genebrina contribuiria para a desconstrução do preconceito contra o ofício de comediante e passaria a valorizar esses artistas fundamentais para o progresso e conservação das artes. Seria interessante que os comediantes fossem orientados por leis salutares e aqueles que fizessem jus poderiam ser colocados no mesmo patamar dos demais cidadãos. Adotando essa posição, a República poderia conquistar algo inusitado: possuir um círculo de comediantes dignos de admiração, sendo apreciada por outros países por ter conseguido reformar a visão comum acerca da figura do comediante. Por conseguinte, Genebra teria um modelo de teatro de comédia caracterizado pelos prazeres honestos, pela filosofia e pela liberdade. O qual se tornaria um exemplo de teatro para toda a Europa.

\section{A objeção de Rousseau}

Em face da proposta da construção de um teatro de comédia em Genebra apresentada pela epistola d'alembertiana, pode-se admitir, inicialmente, que Rousseau expressa uma veemente discordância em relação a ela. É a partir da análise da posição contrária estabelecida por Rousseau que buscaremos demonstrar em que consiste a festa popular e sua função no regime político republicano. Vejamos alguns pontos que compõem a objeção postulada pelo pensador genebrino. Lê-se na réplica efetuada que a melhor forma de se avaliar a qualidade de um espetáculo é por meio de seus resultados na vida de um povo e os gêneros dos espetáculos costumam ser escolhidos conforme o prazer que ele é capaz de oferecer ao invés de suas possíveis vantagens. Talvez existam espetáculos de comédia que sejam capazes de trazer vantagens a um povo, porém, sua finalidade central é a de entreter os espectadores. Rousseau define o teatro como um retrato constituído pelas paixões que residem nos corações humanos, todavia, ressalta que é o afago a tais paixões, estimulado pelos atores, que mantém a atenção do público. Na realidade, os autores teatrais procuram simplesmente forjar suas obras de acordo com as emoções do público, muitas vezes com o intuito de enfatizar as paixões mais convenientes a um determinado público e assim conquistar notoriedade. Na percepção rousseauísta, é improvável crer que o teatro seja capaz de operar uma vicissitude nos sentimentos humanos, e tampouco nos costumes, o que está ao seu alcance é trazê-los à tona 
fidedignamente ou adorná-los.

Rousseau prossegue argumentado que existem somente três formas de se atuar nos costumes de uma sociedade: por meio das leis, da opinião e do prazer produzido pelo divertimento. Ele alega, contudo, que as leis não se aproximam do teatro e uma possível aproximação geraria embaraço e desconforto, ao invés de diversão. Tratando-se da opinião, o genebrino assevera que ela não necessita do teatro, uma vez que o teatro não prescreve "a lei ao público", contrariamente, as obtém dele, e, finalmente, o prazer proporcionado pelo teatro tem como resultado o fato de fazer com que os espectadores voltem a ver o mesmo espetáculo repetidas vezes. A resposta rousseauniana direcionada a D’Alembert avança apresentando uma análise de como algumas representações teatrais deturpam as figuras republicanas de Catão e Cícero ${ }^{5}$; avalia o que se pode aprender com as tragédias gregas Édipo e Médeia ${ }^{6}$; expõe uma feroz crítica à ridicularização da virtude em $\mathrm{O}_{\text {misantropo }}{ }^{7}$, de Molière, discute a questão das mulheres no teatro e explana especificamente a tragédia Berenice, de Racine. Essa trilha é percorrida pelo autor da Carta a D'alembert até desembocar em um critério medular para julgar se é bom ou não a abertura de um teatro nas cidades em geral e também para exprimir sua opinião atinente ao caso de Genebra. Examinemos essas duas ideias.

Primeiramente, tomando como exemplo uma pequena vila montanhosa, caracterizada por costumes frugais e diversões simples, Rousseau elenca quais seriam os cinco possíveis danos que a fundação de um teatro poderia causar para o povoado. Ele as resume assim: a diminuição do trabalho, o crescimento nas despesas, a diminuição das vendas, a criação de novos impostos e a introdução do luxo ${ }^{8}$. Após isso, estabelece o seguinte parâmetro: para

\footnotetext{
${ }^{5}$ Rousseau questiona os efeitos morais devastadores de peças que distorcem a imagem de homens virtuosos e pintam um retrato atrativo de criminosos que, em seu entendimento, provoca em nós certa empatia pelos vilões. Peças nas quais Catão, um exemplo de homem para a humanidade, é representado como um pedante e Cícero um ardente defensor da república - é descrito como um orador repugnante e um covarde, enquanto o conspirador e ignominioso Catilina é mostrado como um homem magnífico dotado de tenacidade e bravura; tais espetáculos são indubitavelmente nocivos aos costumes e à virtude cívica (o amor à pátria e às leis).

${ }^{6}$ Para Rousseau, com a tragédia Édipo somos levados a crer que o homem é destituído de liberdade e que o céu pode penalizá-lo por crimes que o estimulou a perpetrar. Ao passo que em Médeia assimilamos que um ciúme furioso pode transformar uma mãe em uma pessoa impiedosa e cruel. Na interpretação rousseauísta, os gregos sujeitavam-se a ver esses espetáculos por encarnarem na ótica deles as antiguidades nacionais transmitidas ao longo das gerações e para eles fazia sentido rememorar episódios, sendo proposital o verniz colérico dado aos espetáculos. Espetáculos (Édipo) em que um homem mata o próprio pai, desposa a mãe e torna-se irmão e pai de seus filhos e, outro (Médeia), no qual uma mãe assassina os próprios filhos com objetivo de se vingar do pai das crianças, nos causando calafrios na alma não podem ser considerados espetáculos dignos de um povo virtuoso e com costumes simples, argumenta o nosso autor.

${ }^{7}$ Embora admire o teatro de Molière, Rousseau tece uma enérgica crítica à sua obra e identifica em suas peças um repertório imenso de vícios e maus costumes. Ele assinala que o efeito mais daninho nas comédias de Molière consiste em uma constante ridicularização da virtude. Segundo o filósofo genebrino, nas obras de Molière há um frequente escárnio no que tange à bondade e à simplicidade, enquanto a representação da astúcia e da perfídia nos envolve de tal maneira que simpatizamos com os personagens que as personificam.

${ }^{8} \mathrm{O}$ luxo é extremamente pernicioso para os valores republicanos e pode contribuir para o desencadeamento da
} 
avaliar se a inauguração de um teatro pode ser algo bom ou ruim para uma cidade é de extrema importância, de antemão, aferir quais são os costumes prevalecentes na cidade em questão e se eles são bons ou maus. Explicitamente, a comédia não produzirá nenhum prejuízo a um povo, se não houver mais nada capaz de prejudicá-lo. Notamos também que, ao contrário do que pensa D'Alembert, unir espetáculos e bons costumes tendo como amparo leis severas, na visão de Rousseau, pressupõe uma comparação entre a medida das leis com a dimensão dos vícios aos quais elas confrontam. Ora, apenas depois desse cotejamento e atestado se a lei supera o vício é que será possível salvaguardar o emprego das leis. E a percepção mais consistente desses encadeamentos na constelação das ideias republicanas advogada pelo cidadão de Genebra, como se sabe, situa-se na alçada do sábio legislador ${ }^{9}$. Não se trata unicamente de elaborar sucessivas normas com objetivo de aplacar e enfrentar, respectivamente, as possíveis violações e aquelas que se consubstanciam. A elaboração de uma legislação, ainda que voltada exclusivamente para os prováveis dispêndios advindos do teatro, demanda uma abrangente compreensão do povo ao qual ela se direciona e essa complexa tarefa não pode ser desempenhada por qualquer $\mathrm{um}^{10}$.

A segunda ilustração oferecida por Rousseau segue por uma curiosa correlação entre as cidades de Paris e Genebra ${ }^{11}$ que se concatena à sua oposição sobre à fundação de um teatro de comédia na República genebrina, como recomenda D’Alembert. Para o autor da replicação, Rousseau, o amor do povo genebrino ao campo, seus bons costumes e diversões simples, o louvor à liberdade pública o maior valor que esse povo confere ao bem da pátria quando contrastado aos entretenimentos, e ainda a virtude e o patriotismo que eles devotam à sua cidade, somado ao alto custo da instauração e manutenção de um teatro de comédia, que corre o sério risco de não se sair bem sucedido, e as possíveis consequências prejudiciais nos usos e costumes dos genebrinos são vistos como motivos suficientes para se rejeitar a proposta

corrupção. Assim como em outras obras de Rousseau, o luxo na Carta a D'Alembert também é apresentado como algo divergente aos costumes frugais republicanos e em função disso Rousseau o crítica duramente.

${ }^{9}$ Figura excepcional no pensamento de Rousseau, o legislador sugere leis para a república e, mais do que isso, contribui para engendrar um espírito público em cada cidadão, isto é, "transforma a natureza humana", fazendo de indivíduos que agem unicamente em busca da satisfação de seus interesses mais imediatos cidadãos capazes de identificar o bem comum e de defender os fundamentos primordiais da república: igualdade e liberdade. Para um aprofundamento acerca da função do legislador, sugerimos a leitura dos seguintes intérpretes: Roger Masters (1968) e Raymond Polin (1964).

${ }^{10}$ Mas, sim, pela figura do sábio legislador.

${ }^{11} \mathrm{Na}$ Carta a D'Alembert, Rousseau traça um perfil de Paris e Genebra assinalando suas notáveis diferenças, almejando fortificar sua discordância no que tange à criação de um teatro de comédia em sua cidade natal. Ele demonstra uma série de fatores econômicos que perpassavam a manutenção do teatro parisiense e suas peças e como essas demandas são inviáveis economicamente à Genebra, e como contrastam aos costumes simples que the são peculiares. Já na nona caminhada dos Devaneios do caminhante solitário, Rousseau se detém em enfatizar brevemente as diferenças entre as festas populares das duas referidas cidades. 
sugerida por D'Alembert. Depois de explicitar os motivos pelos quais se contrapõe à recomendação d'alembertiana, constata-se na missiva que Rousseau desdobra-se em um endosso que fornece consistência à sua reflexão e ao mesmo tempo provoca a emanação de uma verdadeira exaltação dos costumes republicanos por ele enxergados em Genebra. Nesse sentido, vemos na análise de Rousseau a defesa de que as recreações singelas dos genebrinos estão em concórdia com o ideário republicano. Em seu entendimento, o povo genebrino aprecia viver de maneira habitual, conviver e passear com a família, as mulheres e as meninas costumam frequentar as residências umas das outras para se entreterem com algum jogo de salão, lancharem ou simplesmente saborearem uma boa conversa. São esses divertimentos corriqueiros repletos de despojamento e um ar de candura que combinam com os costumes republicanos. A criação de um teatro de comédia trazendo à tona o luxo e outros valores morais perverteria todo esse ambiente frugal de Genebra.

Rousseau adverte que o fato de os espetáculos modernos poderem ser vistos somente mediante o desembolso de dinheiro ${ }^{12}$, fatalmente contribuiria para o aprofundamento da desigualdade das riquezas. Ele defende que se nas grandes capitais as disparidades entre ricos e pobres usualmente são maquiadas a ponto de serem menos perceptíveis, em uma cidade republicana e menor, como no caso de Genebra, a desigualdade seria assim claramente percebida. Uma vez que, na República os cidadãos são súditos e soberanos concomitantemente, no caso de uma minoria, nesse contexto, tornar-se mais rica do que a maioria, debilitaria a ordenação política e significaria o seu declínio. Independentemente de o rico acumular mais riqueza ou do pobre despencar na indigência, em ambas as maneiras o antagonismo entre as riquezas se aprofundam e é justamente a dilatação dessa discrepância que extirpa o equilíbrio de riqueza que deve predominar na República. A desigualdade começa depauperando os laços entre os cidadãos comprometendo implacavelmente a virtude cívica ${ }^{13}$, pois eles passam a se concentrar apenas nos seus interesses mais prementes e no armazenamento de riqueza em oposição ao empenho na construção do bem comum.

\footnotetext{
12 Assim como nos textos sobre a Córsega e a Polônia, na Carta a D'Alembert observa-se uma crítica virulenta de Rousseau ao dinheiro. Na interpretação de Paule-Monique Vernes (1978), em Rousseau apenas a força humana é real, o dinheiro é uma força imaginária. Logo, o dinheiro personifica o signo que representa a riqueza e a recusa dele na festa significa a abolição de um prazer mercenário. A festa extingue o espaço entre o desejo e o prazer ao banir a representação e o intervalo no qual o dinheiro seria inserido. Jacira de Freitas (2003) destaca, alinhada com Vernes, que Rousseau associa intimamente a degradação do homem a um sistema econômico no qual existe um volumoso giro de dinheiro e o fomento ao luxo material e espiritual. A comentadora afirma ainda que a inexistência do dinheiro e do luxo na festa está em simetria com o modelo de nação caracterizada pela liberdade e cimentada na teoria da riqueza e do sistema econômico autárquico presentes na reflexão rousseauísta.

${ }^{13}$ Que no pensamento de Rousseau consiste no amor à pátria e às leis. A virtude cívica é a mola propulsora que mobiliza os cidadãos a saírem na defesa do bem comum e dos demais valores republicanos.
} 


\section{Festa popular: o espetáculo mais apropriado à República}

Considerando a admoestação empregada por Rousseau à sugestão da criação de um teatro de comédia em Genebra, recomendada por D'Alembert, a um questionamento, ainda que retórico e baseado em uma indagação do próprio Jean-Jacques, se faz necessário reportar: se toda cidade precisa de espetáculos e o genebrino recusa a fundação de um espaço para a apresentação desses divertimentos, isso corresponde a dizer que nenhum tipo de espetáculo convém à República ${ }^{14}$ ? No regime republicano não deve haver qualquer espécie de espetáculo?

A resposta de Rousseau a tais inquietações é negativa. Eis suas palavras:

(...) não deve haver nenhum Espetáculo numa República? Pelo contrário! Deve haver muitos deles. Nas Repúblicas eles nascem, nelas os vemos brilhar com um real ar de festa. A que povos convém mais reunir muitas vezes seus cidadãos e travar entre eles os doces laços do prazer e da alegria, do que aos que têm tantas razões para se amarem e para permanecerem unidos para sempre? Já temos os prazeres dessas festas públicas; tenhamo-nas em ainda maior número, e ficarei ainda mais encantado. Mas não adotemos esses espetáculos exclusivos que encerram tristemente um pequeno número de pessoas num antro escuro; que as mantêm temerosas e imóveis no silêncio da inação; que só oferecem aos olhos biombos, pontas de ferro, soldados, aflitivas imagens da servidão e da desigualdade. Não, Povos felizes, não são essas as vossas festas! É ao ar livre, é sob o céu que devais reunir-vos e entregar-vos ao doce sentimento de vossa felicidade! (ROUSSEAU, 1995, p. 114). ${ }^{15}$

Constatam-se duas ideias fundamentais nessas palavras rousseauístas: primeira, a festa sugerida como contraponto é um espetáculo que se diferencia do teatro. Segunda, a festa é

\footnotetext{
${ }^{14}$ Até esse tópico teremos "República de Genebra" como parâmetro e a Carta a D'Alembert como base. Porém, no próximo (último) tópico ao avaliarmos se a festa popular pode contribuir para a durabilidade do regime republicano, vamos nos valer especialmente das Considerações sobre o governo da Polônia. Ao adotarmos essa posição, visamos ampliar os horizontes, isto é, pensar o lugar e a importância que a festa popular pode ter no regime republicano em geral e não especificamente em Genebra, ainda que a "República de Genebra" nos sirva claramente de eixo e modelo. Justamente, por esse motivo, decidimos, por julgar mais adequado, intitular o nosso trabalho de "A festa popular na república" ao invés de "A festa popular na República de Genebra". Convém frisar também que adotamos o termo "República" com "R" maiúsculo para designar especificamente a "República de Genebra", ao passo que quando empregamos o termo "república" com a "r" minúsculo temos em vista o modelo político republicano no sentido mais amplo da acepção do termo.

${ }^{15}$ (...) ne faut-il donc aucun Spectable dans une République? Au contraire, il en faut beaucoup! C'est dans les Républiques qu'ils sont nés; c'est dans leur sein qu'on les voit briller avec um véritable air de fête. À quels peuples convient-il mieux de s'asembler solvente et de former entre les doux liens du plaisir et de lajoye, qu'a ceux qui ont tant de raisons de s'aimer et de rester à jamais unis? Nous avons déja plusieur de ces fête publiques; ayons-em davantage encore, je n'em serai que plus charme. Mais n'adoptons point ces Spectables exclusifs qui renferment tristemente um petit nombre de gens dans um autre obscur; qui les tiennent craintifs et immobiles dans le silence et l'inaction; qui n'offrent aux yeux que cloisons, que pointes de fer, que soldats, qu'affligeantes images de la servitude et de l'inégalité. Non, Peuples heureux, ce ne sont pas là vos fêtes! C'est em plein air, c'est sous le ciel qu'il faut vous rassembler et vous livrer au doux sentimento de vôtre bonheur. $C D$, OCR5. (Tradução nossa).
} 
popular, pois se realiza ao ar livre. A respeito da primeira constatação, Luc Vincenti (2015) elucida que é com base na duplicidade interior entre "ser" e "parecer" que enrobustece a opinião pública na acepção adotada por Rousseau de estima pública, que o autor genebrino antagoniza a festa popular à representação teatral. A natureza dessa oposição é, sobretudo, política à medida que visa enaltecer as virtudes patrióticas. Ainda sobre essa constatação, Baczko (1978) sinaliza que a festa popular ou cívica diverge do teatro, mas confere à vida pública uma dose de teatralização. Uma vez que cada cidadão é, em potencial, um ator que representa seu papel nesse espetáculo, o qual tem a República como objeto e palco. A segunda constatação diz respeito ao que Vernes (1978) preconiza: a ausência do dinheiro, e todos os objetos que demandariam a intercessão pecuniária na festa, abrem margem para que Rousseau realce a estrita relação do homem com a natureza, isto é, com as árvores, a água, o fogo etc. Sobre os termos em sequência que acabamos de ler, Rousseau sublinha que os prazeres nesses espetáculos republicanos não devem ser lânguidos e nem tampouco mercenários, mas livres, generosos e capazes de resplandecer sob a luz do sol. O pensador de Genebra afirma também que o cidadão republicano não é simplesmente parte do espetáculo, ele é o espetáculo em si. Além disso, interroga-se sobre os objetivos do espetáculo:

(...) quais serão, porém, os objetivos desses espetáculos? Que se mostrará neles? Nada, se quisermos. Com liberdade, em todos os lugares onde reina a abundância, o bem-estar reina também. Plantai no meio de uma praça uma estaca coroada de flores, reuni o povo e tereis uma festa. Ou melhor ainda: oferecei os próprios espectadores como espetáculo: tornai-os eles mesmos atores; fazei com que cada um se veja nos outros para que com isso todos fiquem mais unidos. Não preciso citar os jogos antigos gregos: há outros mais modernos, há os que ainda existem, e os descubro justamente em nossa cidade. Temos revistas todos os anos; prêmios públicos, reis do arcabuz, do canhão, da navegação. Nunca é demais multiplicar eventos tão uteis ${ }^{16} \mathrm{e}$ tão agradáveis (...) (ROUSSEAU, 1995, p. 115). ${ }^{17}$

\footnotetext{
${ }^{16}$ Em nota de rodapé, o filósofo genebrino esclarece que além de ter pão na mesa é necessário que haja um ambiente agradável para que os cidadãos exerçam seus deveres e a ordem pública se consolide. Para uma primazia dos bons costumes é crucial que cada cidadão esteja satisfeito com a sua própria condição. E para que um povo se torne dinâmico e trabalhador é impreterível que existam festas e recreações hábeis em fazê-lo reconhecer e amar a sua condição.

17 (...) quels seront enfin les objets de ces spectables? Qu'y montrera-t-on? Rien, si l'on veut. Avec la liberte, partout où régne l'aflluence, le bien-être y régne aussi. Plantez au milieu d'une place um piquet couronné de fleur, rassemblez le peuple, et vous aurez une fête. Faites mieux encore: donnez les Spectableur em Spectable; rendezles acteurs eux-mêmes; faites que chacun se voye et s'aime dans les autres, afin que tous em soient mieux unis. Je n'ai pas besoin de renvoyer aux jeux des anciens Grecs; il em est de plus modernes, il em est d'existen encore, et j eles trouve précisement parmi nous. Nous avons tous les ans des revues, des prix publics, des Rois de l'arquebuse, du canon, de la navigation; on ne peut trop multiplier des établissemens si utiles et si agréables (...). $C D$, OCR5 (Tradução nossa).
} 
Rousseau destaca, por um lado, que essas festas têm baixo orçamento e a grande participação das pessoas contribui diretamente para torná-las admiráveis. Por outro, exalta-se ao falar sobre como os genebrinos se mostram irreconhecíveis em tais eventos. Inseridos na atmosfera das festividades populares, ele é vivo, alegre, carinhoso e o seu coração passa a estar nos olhos, como sempre está nos lábios (ROUSSEAU, 1995, p. 116) ${ }^{18}$, se mobilizam em enunciar o quão alegres ${ }^{19}$ ficam por ali estarem e igualmente, em decorrência disso, expressarem prazer. A unidade da República se mostra nítida nessas festas, nas quais a união de todos os cidadãos forma uma integridade moral e política, isto é, tudo se torna comum a todos.

Além da inexistência de orçamento, as festas são espetáculos que tornam a cidade um lugar encantador e alegre. Não é o modelo de teatro de comédia importados de Paris e Londres, portanto, que contribuirá para guardar no coração dos cidadãos genebrinos o amor à pátria e o comprometimento com o bem público. Em contrapartida, verifica-se que em Rousseau serão as reminiscências dos primeiros exercícios ${ }^{20}$ e espetáculos populares e cívicos que presenciaram ou participaram quando crianças e jovens e os primeiros contentamentos - extraídos dessas experiências - que se conservam entranhados em seus corações. Para que as ternas experiências patrióticas vivenciadas na juventude se perpetuem de maneira vigorosa na maturidade e velhice dos cidadãos, é imperioso que exista uma voz no recôndito da alma de cada cidadão que seja capaz de reportá-los, ainda que pela memória, às festividades da juventude, na qual expressavam a harmonia entre os cidadãos, a fraternidade pública, assim como a alegria, a igualdade e a liberdade. Destarte, as festividades constituem-se um ambiente no qual uma verdadeira veneração à pátria encontra-se resguardada em uma ordenação republicana justa.

Para consolidar o seu ponto de vista, nos últimos momentos da Carta a D'Alembert Rousseau remete-se a um dos arquétipos que lhe servem de base para a composição do seu ideário republicano: Esparta. Segundo o escritor genebrino, enquanto em Atenas havia o culto às belas-artes, ao luxo e à frouxidão, em Esparta havia festas modestas, jogos e espetáculos. Na última cidade aludida, os trabalhos mais penosos eram tidos como recreação, os lazeres mais

\footnotetext{
${ }^{18}$ Il est vif, gai, carressant; son couer est alors dans ses yeux, comme il est toujours sur ses lévres. $C D$, OCR5. (Tradução nossa).

${ }^{19} \mathrm{Na}$ nona caminhada dos Devaneios, Rousseau remete à essa ilustração sobre o comportamento dos genebrinos nas festas populares. Ele escreve que nas festas populares em Genebra o riso é permanente, respira-se contentamento e alegria, assim como o bem-estar, a fraternidade e a harmonia imperam nos corações dos cidadãos. Essas singularidades são tão evidentes que, espontaneamente, desconhecidos adentram nas festividades e se abraçam deleitando-se com os prazeres proporcionados por aquela harmonia.

${ }^{20}$ Rousseau frisa a importância das atividades físicas para tornarem os cidadãos robustos e dispostos à defesa da pátria.
} 
singelos colaboravam de maneira direta para a instrução pública; os cidadãos se reuniam com frequência, se dedicavam aos divertimentos populares e aos jogos que ocupavam um importante lugar no Estado. Pode-se atestar que Rousseau tem nessa cidade também um modelo de festa popular ou cívica. Na percepção do filósofo, Esparta oferece o melhor paradigma de festas para Genebra, principalmente porque os divertimentos espartanos se caracterizavam pela simplicidade, ausência de ostentação e um fascinante patriotismo que temperava o espírito guerreiro adequado aos homens livres ${ }^{21}$. Tais recreações eram desfrutadas pelos cidadãos com disposição, jovialidade e entusiasmo pela pátria.

$\mathrm{O}$ autor encerra a sua missiva de refutação nos oferecendo uma amostra de uma festa republicana que ele extraiu de uma narrativa de Plutarco. Rousseau assim a narra:

Havia (...), sempre três danças em igual número de grupos, de acordo com a diferença de idade; e essas danças ${ }^{22}$ se davam ao canto de cada grupo. A dos velhos começava primeiro, cantando a seguinte copla: Nós fomos antigamente jovens, valentes e ousados. Seguia-se a dos homens, que cantavam, por sua vez, batendo as armas e cadencialmente: Nós $o$ somos agora, à prova, para o que der e vier. Em seguida, vinham as crianças, que lhes respondiam, cantando com toda a força: E nós logo o seremos, e a todos vós superaremos. (ROUSSEAU, 1995, p. 124). ${ }^{23}$

Nesse derradeiro fragmento, nota-se que o modelo de festa popular ao qual Rousseau tem em vista encontra-se diretamente ligado a uma de suas referências antigas fundamentais. Há que se observar também que o trecho se mobiliza em explicitar a transmissão e a afirmação da bravura dos cidadãos virtuosos e sua disposição em defender a pátria ao longo das gerações. Isso salienta-se na intrepidez patriótica que vemos reiterada na canção, ao se tornar mais robusta

\footnotetext{
${ }^{21}$ Em nota de rodapé, Rousseau narra uma recordação de infância que serve de exemplo para confirmar a sua imagem de "festa". Ele relata que um dia a tropa de Saint-Gervais, depois de realizar seus exercícios regulares e se alimentarem, se aglomeraram na Praça de Saint-Gervais. Cerca de quinhentos ou seiscentos homens, entre eles oficiais e soldados, começaram a dançar de mãos dadas em torno da fonte seguindo uma longa fita que se contorcia entre inúmeras idas e vindas. Essa festividade despertou do sono as pessoas que moravam ao redor. Primeiramente elas se debruçaram sob suas janelas para contemplar o espetáculo, depois não se dando por satisfeitas, desceram de suas casas e se juntaram aos protagonistas da festa. O cidadão de Genebra afirma que quando a dança se encerrou, o seu pai lhe proferiu as seguintes palavras: "Jean-Jacques (...) ama teu país. Vê esses bons genebrinos; são todos amigos, todos irmãos; a alegria e a concórdia, reina entre eles. Tu és genebrino: um dia verás outros povos; mas, mesmo que venhas a viajar tanto quanto teu pai, nunca encontrarás um povo igual a este". (p. 146, nota 64.).

${ }^{22}$ Sobre esse tema sugere-se ver mais em Jacira de Freitas (2003), p. 129-138.

${ }^{23}$ Il y avoit, (...), toujour trois danses em autant de bandes, selon la difference des âges; et ces danses se faisoient au chant de chaque bande. Celle des vieillard commençoit la première, em chantant le couplet suivant, Nous avons été jadis, Jeunes, vaillans, et hardis. Suivoit celles des hommes, qui chantoient à leur, em frappant de leur armes en cadence. Nous le sommes maintenant, À l'épreuve à tout venant. Ensuite venoient les enfans qui leur répondoient, em chantant de toute leur force. Et nous bientôt le serons, qui tous vous surpasserons. CD, OCR5 (Tradução nossa).
} 
a cada geração.

\section{A festa popular pode contribuir para a durabilidade da república?}

O tema da festa popular não se esgota na Carta a D'Alembert, também encontramos uma importante descrição acerca das festividades republicanas nas Considerações sobre o governo da Polônia ${ }^{24}$. No capítulo III dessa obra, Rousseau sugere que é necessário que haja vários jogos públicos ${ }^{25}$ organizados e cuidados pela pátria - esse cuidado fará com que os cidadãos se sintam amparados e se interessem por ela -; e que sejam suprimidos os entretenimentos peculiares às capitais como os espetáculos de comédia, assim como todo tipo de distração que os afastem da pátria e de seus deveres públicos. Logo, é primordial criar jogos, festivais e cerimônias estritamente nacionais. Os espetáculos devem ocorrer ao ar livre com a igual participação do povo, pois os ambientes públicos demandam um ornamento altivo para que tenha a capacidade de sensibilizar o coração dos cidadãos e as cerimônias precisam expressar um ar de ordem ${ }^{26}$, hábil o suficiente em incutir confiança e afugentar imagens e opiniões ligadas a concepções de poder despótico. Para tanto, é fundamental que não exista nas comemorações enfeites luxuosos que produzam um deslumbramento cego, como costuma

\footnotetext{
${ }^{24}$ Segundo Luc Vincenti, Rousseau retoma as temáticas da Carta a D’Alembert nas Considerações sobre o governo da Polônia. Concordamos plenamente com essa conexão que o pesquisador delimita entre as duas obras, deve-se dizer, todavia, que o tema ao mesmo tempo resvala com outra roupagem na carta VII da Quinta parte da Nova Heloísa que trata da ordem e alegria na casa do Sr. de Wolmar durante a festa das Vindimas de Clarens e também na nona caminhada dos Devaneios do caminhante solitário. No que tange à festa na Nova Heloísa, Starobinski (1991) destaca que a igualdade não condiz com a estrutura de Clarens, mas se instala no momento da festa. As Vindimas proporcionam um momento de igualdade na partilha do trabalho entre os moradores (a festa é um dia de trabalho, no qual a produção ultrapassa consideravelmente as despesas) embora a personagem Júlia se coloque no centro da celebração. Na nona carta dos Devaneios, o próprio Rousseau ocupa o centro da festa ao distribuir guloseimas para um grupo de meninas e com essa distribuição almeja estabelecer uma igualdade entre elas e uma alegria mais geral, como escreve Rousseau. O intérprete frisa, além disso, que o modelo ideal democrático, alicerçado na igualdade visto no Contrato social, se diferencia frontalmente da "estrutura ainda feudal da comunidade de Clarens" uma vez que o pensador genebrino busca reparar a desigualdade vigente na ordenação cotidiana de Clarens por meio da festa. Para uma compreensão mais abrangente acerca das distinções entre essas festas na teoria rousseauísta, sugere-se além da leitura de Starobinski, p. 98-108, Jacira de Freitas (2003) e Luc Vincenti (2015). Cabe registrar, sem desconsiderar as particularidades das festividades aludidas, que as festas populares presentes na Carta a D'Alembert e nas Considerações são as que melhores representam a visão política republicana de Rousseau.

${ }^{25}$ Starobinski (1991) ressalta que as festas e os jogos públicos se configuram em dispositivos sugeridos por Rousseau para colocar a lei acima dos homens e inserir o amor à pátria no coração dos cidadãos. O estudioso advoga que no âmbito da festa a igualdade se expressa na participação de todo o povo no espetáculo; é imprescindível para o pensador de Genebra que a igualdade seja efetiva como alma coletiva. Viroli (2002) enfatiza que jogos públicos, e simultaneamente as festas, a educação nacional e as cerimônias públicas notabilizam o caráter nacional do povo e se revelam como um reforço para o amor à pátria, a construção da identidade comum e o desejo de salvaguardar a comunidade. Tais pressupostos são condição para a instauração de uma consciência cívica em cada cidadão.

${ }^{26}$ Para uma compreensão mais abrangente da ideia de "ordem" na festa sugerimos as seguintes referências: PauleMonique Vernes (1978) e Luc Vincenti (2015).
} 
acontecer nas cortes. As festas singulares a um povo livre pressupõem equilíbrio, simplicidade e honradez e apenas os objetos realmente merecedores de admiração devem fazer parte da ornamentação e, evidentemente, nesses eventos o luxo ${ }^{27}$ deve ser rechaçado.

Na leitura de Paule-Monique Vernes, a festa em Rousseau tem um forte apelo à nacionalização, isto é, ela é polonesa ou genebrina e se refere exclusivamente a uma nação. A intérprete sublinha que na Carta a D'Alembert o cidadão de Genebra confere à festa duas acepções distintas: a festa patriótica e a festa de Saint-Gervais ${ }^{28}$. Na festa "patriótica", ou "popular", o governo estabelece as datas, os ambientes, os ritos e a sua função é a de estreitar os elos do povo e instituir um momento para se experimentar com perspicácia a concepção de comunidade. A festa "patriótica" coloca em cena a consagração da vontade geral e impõe a reciprocidade entre os cidadãos, ao invés de uma hierarquia social. Rousseau produz uma visão ideológica da festa, porém, a totalidade à qual ele alude não é a da humanidade, mas sim à de uma pátria específica que se distingue da festividade espontânea do exemplo dado pelo autor da festa de Saint-Gervais. Sob o prisma de Baczko (1978), Rousseau legou à geração ${ }^{29}$ que lhe sucedeu, por um lado, o protótipo de festa quimérica e a nostalgia da mesma, e, por outro, um sistema ou ideologia da festa e uma reflexão sobre sua provável aplicabilidade estritamente política na organização de educação pública. O cânone de festa ideal se segmenta em uma especulação sociológica e política, logo, ela tem a possibilidade de ser utilizada como ação política e ideológica. Vê-se que Rousseau sabia os resultados que as festas poderiam causar na alma de cada cidadão, e especialmente em sua imaginação pois o modelo de festa referido introduziria na imaginação dos cidadãos os valores públicos firmados no espetáculo pelos ritos e pela linguagem simbólica que o constitui; todos os elementos que o compõe rememoram a vida coletiva e impulsionam uma emoção direcionadas para a liberdade e a pátria. O estudioso explica que a festa pode servir de ferramenta para difundir em seus partícipes a ideia de igualdade entre eles. Os jogos e os símbolos que a adornam contribuem para que ela se inscreva como um rito de uniformidade e fraternidade capaz de propiciar aos cidadãos o mesmo júbilo. Eles se elevam acima de si mesmos mediante a imaginação orientada pela esfera do possível na política. Daí se origina o efeito educativo da festa e sua decisiva função na estrutura de educação

\footnotetext{
${ }^{27}$ Mais uma vez Rousseau se opõe ao luxo ao enfatizar nas Considerações sobre o governo da Polônia o quão ele pode ser pernicioso até mesmo nas festas populares e cerimônias cívicas.

28 Descrevemos o caráter espontâneo dessa festa na nossa nota 20, agora vamos nos deter em apenas tentar compreender o que significa a "festa patriótica" para Vernes. Aliás, o que a comentadora denomina de "festa patriótica" é o que entendemos como "festa popular" em Rousseau, conforme segue a abordagem.

29 Backzo defende no mesmo texto que a geração dos revolucionários franceses, influenciada pela filosofia rousseauniana, se abasteceu tanto do modelo quanto da teoria e buscou empregar ambos os elementos para definirem as experiências de novas expressões de festividades.
} 
pública: os cidadãos se tornam protagonistas da festa, e mais do que festejar, se autoeducam por meio do espetáculo. Percebe-se, assim, a dupla missão da festa: ela é consolidadora, pois retrata e expande os valores primordiais que sustentam a ordenação social, e também é mobilizadora, na medida em que desencadeia e conduz as energias ${ }^{30}$ em direção aos valores públicos.

Constata-se em Rousseau uma utopia e teoria de "festa patriótica" ou "popular", somadas a normas sistemáticas para viabilizar uma ação sobre as almas dos cidadãos, objetivando a apreensão de determinas concepções políticas e padrões de conduta. Diante da explanação realizada - com o suporte indispensável dos intérpretes dos quais nos servimos para se compreender o significado da "festa popular" na abordagem republicana de Rousseau -, cumpre analisar uma última questão: de que maneira a festa popular pode contribuir, dentro da engrenagem política, para a durabilidade da república? Entendemos que a festa popular pode ser admitida como um pertinente recurso para assegurar a conservação do regime republicano. Preconiza-se essa leitura porque avaliamos que a festa confecciona e afirma o caráter nacional de um povo, consagra e reaviva os valores fundamentais da república, contribui abertamente para que os cidadãos reconheçam uns nos outros tais valores, edificando uma identidade comum, e enrobustecendo suas consciências cívicas. A festa popular ativa o patriotismo que cada cidadão traz em seu coração e os vincula por esse sentimento. Essas peculiaridades nos permitem inferir que tal celebração, ao impelir o desabrochar do amor à pátria e fomentar a instauração de uma consciência coletiva em cada cidadão, repercutirá prontamente na vida da república, posto que, quanto mais os cidadãos se reconhecerem como membros de uma ordenação republicana e orientarem suas ações a partir do sentimento de pertencimento, maiores serão as chances de eles advogarem em favor dos princípios políticos que formam o regime. A festa popular pode ser utilizada para manter a sobrevivência do regime republicano em longo prazo e o seu quinhão encontra-se inerente ou complementa a virtude cívica, visto que envolve de modo frontal a construção da figura do cidadão e reforça nele uma memória afetiva concernente à república e seus valores.

\section{Bibliografia}

BACZKO, Bronislaw. Lumière de l'utopie - critique de la politique. Paris: Payot, 1978.

FREITAS, J. Política e festa popular em Rousseau: a recusa da representação. São Paulo: Humanitas, 2003.

${ }^{30} \mathrm{O}$ pesquisador lembra que esse é o termo usado por Rousseau nas Considerações. 
MASTERS, Roger D. The political philosophy of Rousseau. Princeton: University Press, New Jersey, 1968.

POLIN, R. La fonction du législateur chez J.-J. Rousseau. In Jean-Jacques Rousseau et son Oeuvre. Problèmes et Recherches. Paris: Klincksieck, 1964.

ROUSSEAU, J.-J. Oeuvres complètes. Paris: Gallimard, Volumes I, II, III et IV - 1959, 1961, 1964, 1969. (Bibliothèque de La Pléiade).

Rousseau e as relações internacionais. São Paulo: Imprensa Oficial do Estado e Editora Unb, 2003.

Carta a D’Alambert. São Paulo: Unicamp, 1993.

Confissões. São Paulo: Edipro, 2008.

STAROBINSKI, Jean. Jean-Jacques Rousseau: a transparência e o obstáculo. São Paulo: Companhia das Letras, 1991.

VERNES, Paule-Monique. La ville, la fête, la démocratie - Rousseau et les illusions de la communauté. Paris: Payot, 1978.

VINCENTI, Luc. Rousseau e a ordem da festa. Trans-Form-Ação. Marília-SP: Ed. UNESP, v. 38 , p. $15-26,2015$.

VIROLI, Maurizio. Jean-Jacques Rousseau and the 'well-ordered society'. Cambridge: Cambridge University Press. UK, 2002. 